\title{
Polyherbal Formulation for Kidney and Liver Protection
}

\author{
S J Kabilan, R Baskar, G Poorani
}

\begin{abstract}
The objectives of the study were to assess the potential of herbal formulation made up of Wedeliachinensis leaves and Boerhaaviadiffusa roots in possessing activities like nephroprotectivity and hepatoprotectivity. Nephroprotective and hepatoprotective activity was evaluated using MTT cytotoxicity assay using mammalian cell culture. The results of the hepatoprotective and nephroprotective activities showed that the formulation mixture of herbs Wedeliachinensis and Boerhaaviadiffusa roots is an excellent source of organ stimulator with high therapeutical importance. The hepatoprotective and nephroprotective properties make this formulation a unique one focusing on liver and kidney diseases.
\end{abstract}

Keywords: Hepatoprotectivity, Nephroprotectivity, Polyherbal formulation

\section{INTRODUCTION}

Nephroprotectivity is an activity of any compound protecting the kidney cells and functions [2]. Likewise, hepatoprotectivity was to protect the liver cells from harmful substances [7]. The above mentioned herbal plants contain few phytoconstituents that possess the ability to act as a nephroprotectant and hepatoprotectant [10]. They play a major role in maintenance of these organs and preventing them from getting damaged [19]. They also boost up their performance and have a cleansing activity on them [20]. They prevent aging of cells present in those organs keeping them healthy for longer time [21].

Wedeliachinensis (Manjalkarisalai in Tamil), Asteraceae is a well reputed herbal medicine in Siddha, Ayurvedha and Unani system of traditional medicine. Recent studies show the presence of diterpenes, flavanoids, triterpenes, phytosteroids and saponins. It is also reported to possess anti-inflammatory, antioxidant, analgesic, hepatoprotective, antimicrobial, CNS depressant, wound healing, antistress and anticancer activity [5].

Boerhaaviadiffusa (Mookirattaikeerai in Tamil) is one of the well known medicinal plants that are used to treat variety of human diseased conditions as mentioned in Ayurveda, Charaka Samhita, and Sushrita Samhita. Huge variety of phytochemicals like flavonoids, alkaloids, glycosides, rotenoids, steroids, triterpenoids, lipids, lignans, carbohydrates, proteins, and glycoproteins etc have been reported from the herb. The promising therapeutic effects of this plant include diuretic, hepatoprotective, anti-inflammatory, anti-cancer, anti-fibrinolytic,

immuno-modulatory, anti-diabetic, immuno-suppressive, analgesic, anti-lymphoproliferative and used for the treatment of TB [11].

Revised Manuscript Received on December 16, 2019.

* Correspondence Author

S J Kabilan*, Department of Biotechnology, Kalasalingam Academy of Research and Education, Krishnankoil, Tamilnadu, India. Email: sjkabil@gmail.com

R Baskar, Department of Biotechnology, Kumaraguru College of Technology, Coimbatore, India. Email:baskar.r.bt@kct.ac.in Technology, Coimbatore, India. Email: gpoorani.biotech@gmail.com
G Poorani, Department of Biotechnology, Kumaraguru College of

The aim of this study is to develop an herbal formulation that possesses nephroprotective and hepatoprotective activity.

\section{MATERIALS AND METHODS}

\section{A. Chemicals}

DMEM medium, Fetal Bovine Serum (FBS), Trypsin, Saline, $\mathrm{H}_{2} \mathrm{O}_{2}$.

\section{B. Sample Collection and Extraction \\ Sample Collection}

Wedeliachinensis leaves and Boerhaaviadiffusa root powder were collected from an FSSAI approved herbal powder manufacturer from Coimbatore, Tamil Nadu. All herbs were stored in air- tight, light resistant container for further use. The samples were labeled as the Wedeliachinensis leaves (WC), Boerhaaviadiffusa (BD) and Formulation mix.

\section{Sample extraction}

About 20g of powdered mix of these herbs was successively extracted with $150 \mathrm{ml}$ of distilled water. Then it is allowed to evaporate in open air to obtain aqueous extracts. The extracts were filtered using membrane filter.

\section{Determination of Hepatoprotective activity}

Human liver HepG2 cells were exposed to a medium containing $\mathrm{H}_{2} \mathrm{O}_{2}(1 \mathrm{mM})$ along with /without various concentrations of the formulation $(100,200,300,400$ and $500 \mathrm{mg} / \mathrm{ml}$ ). Then cytotoxicity was assessed by estimating the viability of HepG2 cells by MTT reduction assay. HepG2 cells were grown in DMEM culture medium and made into single-cell suspension and seeded into a 96-well flat bottom plate with $1 \times 104$ cells per well. After $48 \mathrm{hr}$ incubation, 100 $\mu \mathrm{L}$ of $1 \mathrm{mM} \mathrm{H}_{2} \mathrm{O}_{2}$ was added to each well followed by the addition of $100 \mu \mathrm{L}$ diluted extract at varying concentrations to the appropriate wells and the plates were incubated for further $48 \mathrm{hr}$ at $37^{\circ} \mathrm{C}$ in a humidified incubator with $5 \% \mathrm{CO}_{2}$. Supernatant was removed from each well, and $100 \mu \mathrm{L}$ of MTT $(0.5 \mathrm{mg} / \mathrm{mL})$ was added. MTT enters the cell's mitochondria, where it is reduced to an insoluble, colored (dark purple) formazan product. The cells were then solubilized with $100 \mu \mathrm{L}$ of an organic solvent DMSO and the released, solubilized formazan reagent is measured spectrophotometrically.

Hepatoprotective activities of the formulation extracts are measured against the toxicity caused by $\mathrm{H}_{2} \mathrm{O}_{2}$ on the liver cells and the readings were obtained at $540 \mathrm{~nm}$ (Surendran et al., 2011).

\section{Determination of in-vitro nephroprotective activity}

Fresh African green monkey normal kidney cells (Vero) were grown in DMEM culture medium and made into 
single-cell suspension and seeded into a 96-well flat bottom plate with $1 \times 104$ cells per well. After $24 \mathrm{hr}$ incubation, $100 \mu \mathrm{L}$ of $1 \mathrm{mM} \mathrm{H} \mathrm{H}_{2} \mathrm{O}_{2}$ was added to each well followed by the addition of $100 \mu \mathrm{L}$ diluted extract at varying concentrations to the appropriate wells and the plates were incubated for further $24 \mathrm{hr}$ at $37^{\circ} \mathrm{C}$ in a humidified incubator with $5 \% \mathrm{CO}_{2}$. Supernatant was removed from each well, and $100 \mu \mathrm{L}$ of MTT $(0.5 \mathrm{mg} / \mathrm{mL})$ was added. MTT enters the cell's mitochondria, where it is reduced to an insoluble, colored (dark purple) formazan product. The cells are then solubilized with $100 \mu \mathrm{L}$ of an organic solvent DMSO and the released, solubilized formazan reagent is measured spectrophotometrically. Nephroprotective activities of the formulation extracts are measured against the toxicity caused by $\mathrm{H}_{2} \mathrm{O}_{2}$ on the liver cells and the readings were obtained at $540 \mathrm{~nm}$ (Srinivasan et al., 2015).

\section{RESULTS AND DISCUSSION}

\section{A. Determination of Hepatoprotective activity}

Hepatotoxicity was induced by $\mathrm{H}_{2} \mathrm{O}_{2}$ in $\mathrm{HepG} 2$ cell lines. Formulation extract has been evaluated for its hepatoprotectiveness. The presence of phytoconstituents in formulation mix extract has inhibited the induced hepatotoxicity.

Table I shows the \% of cell death occurred due to toxicity induced by $\mathrm{H}_{2} \mathrm{O}_{2}$ with or without different concentration of Formulation extracts.

Table I: Percentage cell death upon $\mathrm{H}_{2} \mathrm{O}_{2}$ toxicity in HepG2 cell lines

\begin{tabular}{|l|l|l|}
\hline S.No & $\begin{array}{l}\text { Test Concentration } \\
(\mu \mathrm{g} / \mathrm{ml})\end{array}$ & $\begin{array}{l}\text { \% of cell death in } \\
\text { presence of } \\
\text { formulation }+\mathrm{H}_{2} \mathrm{O}_{2}\end{array}$ \\
\hline 1 & 100 & $66.27 \pm 2.68$ \\
\hline 2 & 200 & $54.25 \pm 2.63$ \\
\hline 3 & 300 & $49.85 \pm 3.51$ \\
\hline 4 & 400 & $43.98 \pm 5.3$ \\
\hline 5 & 500 & $35.19 \pm 5.85$ \\
\hline $\mathrm{H}_{2} \mathrm{O}_{2}$ toxic control & $88.56 \pm 1.75$ \\
\hline
\end{tabular}

The above data shows that with increasing concentration of formulation, the cell death has been reduced, which shows the protective activity of the formulation.

Table II: Hepatoprotective activity of formulation mix over toxicant in HepG2 cell line

\begin{tabular}{|l|l|c|}
\hline S.No & $\begin{array}{l}\text { Test Concentration } \\
(\mu \mathrm{g} / \mathrm{ml})\end{array}$ & $\begin{array}{l}\text { \% Protection } \\
\text { offered over } \\
\text { toxicant control }\end{array}$ \\
\hline 1 & 100 & $25.16 \pm 3.03$ \\
\hline 2 & 200 & $38.74 \pm 2.98$ \\
\hline 3 & 300 & $43.70 \pm 3.97$ \\
\hline 4 & 400 & $50.33 \pm 5.98$ \\
\hline 5 & 500 & $60.26 \pm 6.61$ \\
\hline
\end{tabular}

Figure 1: Percentage hepatoprotectivity of formulation mix over toxic control

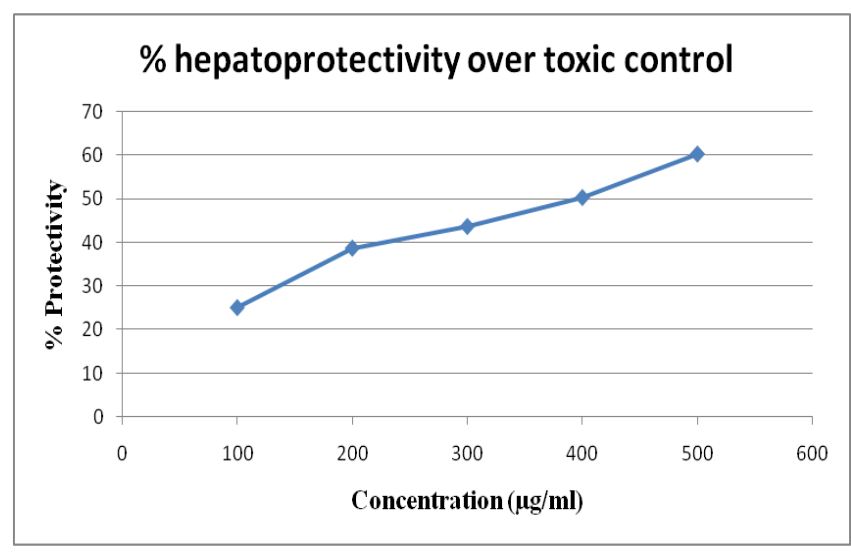

The PC50 (Protective Concentration 50\%) is $381.48 \mu \mathrm{g} / \mathrm{ml}$ which results in better hepatoprotective activity over the $\mathrm{H}_{2} \mathrm{O}_{2}$ toxicity in HepG2 cells.

It has been revealed from Table II, that effective protection of about $50 \%$ over toxicant control has been attained at $381.48 \mu \mathrm{g} / \mathrm{ml}$ concentration (Srinivasan et al., 2015). Both the Boerhaaviadiffusa and Wedeliachinensis possess hepatoprotective activity and contains phytoconstituents having hepatoprotective activity.

\section{B. Determination of nephroprotective activity}

Nephrotoxicity was induced by $\mathrm{H}_{2} \mathrm{O}_{2}$ in Vero cell lines. Formulation mix extract has been evaluated for its nephroprotectiveness. The presence of various phytoconstituents and minerals in formulation mix extract has inhibited the induced nephrototoxicity (Ahmed et al., 2010).

Table III shows the $\%$ of cell death occurred due to toxicity induced by $\mathrm{H}_{2} \mathrm{O}_{2}$ with or without different concentration of formulation mix extracts.

Table III: Percentage cell death upon $\mathrm{H}_{2} \mathrm{O}_{2}$ toxicity in Vero cell lines

\begin{tabular}{|l|l|l|}
\hline S.No & $\begin{array}{l}\text { Test Concentration } \\
(\mu \mathrm{g} / \mathrm{ml})\end{array}$ & $\begin{array}{l}\text { \% of cell death in } \\
\text { presence of } \\
\text { formulation }+\mathrm{H}_{2} \mathrm{O}_{2}\end{array}$ \\
\hline 1 & 100 & $89.63 \pm 0.44$ \\
\hline 2 & 200 & $88.34 \pm 0.77$ \\
\hline 3 & 300 & $83.41 \pm 0.44$ \\
\hline 4 & 400 & $67.09 \pm 1.18$ \\
\hline 5 & 500 & $63.21 \pm 1.18$ \\
\hline $\mathrm{H}_{2} \mathrm{O}_{2}$ toxic control & $93.26 \pm 0.44$ \\
\hline
\end{tabular}

From the table, it is evident that the $\mathrm{H}_{2} \mathrm{O}_{2}$ toxicity was inhibited with increasing concentration of formulation.

Tabe IV: Nephroprotective activity of formulation mix over toxicant in Vero cell line 


\begin{tabular}{|l|l|l|}
\hline S.No & $\begin{array}{l}\text { Test Concentration } \\
(\mu \mathrm{g} / \mathrm{ml})\end{array}$ & $\begin{array}{l}\text { \% Protection } \\
\text { offered over } \\
\text { toxicant } \\
\text { control }\end{array}$ \\
\hline 1 & 100 & $3.89 \pm 0.48$ \\
\hline 2 & 200 & $5.28 \pm 0.83$ \\
\hline 3 & 300 & $10.56 \pm 0.48$ \\
\hline 4 & 400 & $28.06 \pm 1.27$ \\
\hline 5 & 500 & $32.22 \pm 1.28$ \\
\hline
\end{tabular}

Figure 2: \% nephroprotectivity of formulation mix over toxic control

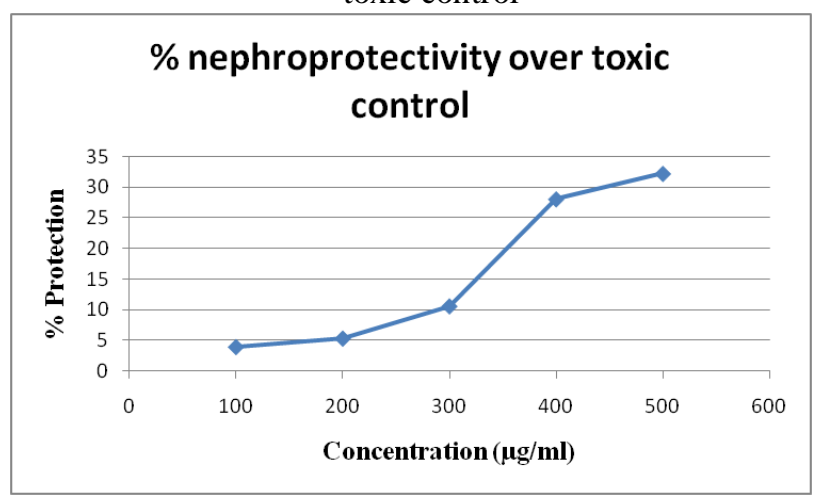

The PC50 (Protective Concentration 50\%) is $732.06 \mu \mathrm{g} / \mathrm{ml}$

It has been shown from Table IV, that effective protection of about $50 \%$ over toxicant control has been attained at $732.06 \mu \mathrm{g} / \mathrm{ml}$ concentration (Kiruba et al., 2014). Boerhaaviadiffusa possess nephroprotective activity and contains phytoconstituents having nephroprotective activity which results in moderate nephroprotective activity over the $\mathrm{H}_{2} \mathrm{O}_{2}$ toxicity in Vero cells.

\section{CONCLUSION}

The results of hepatoprotective and nephroprotective activities showed that the formulation mixture of herbs Wedeliachinensis and Boerhaaviadiffusa roots is an excellent source of organ protector with high therapeutical importance. The hepatoprotective and nephroprotective properties make this formulation a unique one focusing on liver and kidney diseases. It may therefore be recommended for people to prevent and get rid of kidney and liver related disorders.

\section{ACKNOWLEDGMENT}

The authors acknowledge Department of Biotechnology and Re forum (Research Cell) of KCT for providing essential facilities and funding to perform the research.

\section{REFERENCES}

1. Ahmed, Mahgoub M. (2010). "Biochemical studies on nephroprotective effect of carob (Ceratonia siliqua L.) growing in Egypt." Nature and Science, Vol. 8, 3: 41-47.

2. Alshawsh, M. A., Abdulla, M. A., Ismail, S., \& Amin, Z. A. (2011). Hepatoprotective effects of Orthosiphon stamineus extract on thioacetamide-induced liver cirrhosis in rats. Evidence-Based Complementary and Alternative Medicine, 2011.

3. Fotakis, G., \& Timbrell, J. A. (2006). In vitro cytotoxicity assays: comparison of LDH, neutral red, MTT and protein assay in hepatoma cell lines following exposure to cadmium chloride. Toxicology letters, 160(2), 171-177.
4. Hassan, S. W., Salawu, K., Ladan, M. J., Hassan, L. G., Umar, R. A., \& Fatihu, M. Y. (2010). Hepatoprotective, antioxidant and phytochemical properties of leaf extracts of Newbouldia laevies. International Journal of Pharm Tech Research, 2(1), 573-584.

5. Herberg, J., Pahari, A., Walters, S., \& Levin, M. (2009). Infectious diseases and the kidney. In Pediatric Nephrology(pp. 1235-1273) Springer Berlin Heidelberg.

6. Kanniparambil Xavier, S., Haneefa, S. M., \& Anand, D. R. (2017). Antioxidant and nephroprotective activities of the extract and fractions of Homonoia riparia Lour. Pharmacognosy magazine, 13(49), 25.

7. Kiruba, Arun K. P., Brindha P. (2014). In vitro studies on nephroprotective efficacy of Cynodon dactylon and Gmelina asiatica, Asian journal of pharmaceutical and clinical research, 7, 111-120.

8. Koul, S., Pandurangan, A., \& Khosa, R. L. (2012). Wedelia chinenis (Asteraceae)-an overview. Asian Pacific Journal of Tropical Biomedicine, 2(2), S1169-S1175.

9. Lakshmi, M. S., Reddy, U. K., \& Rani, S. R. K. S. (2012). A review on medicinal plants for nephroprotective activity. Asian J Pharm Clin Res, 5(4), 8-14.

10. Mahesh, A. R., Kumar, H., Ranganath, M. K., \& Devkar, R. A. (2012). Detail study on Boerhavia Diffusa plant for its medicinal importance-a review. Res J Pharm Sci, 1, 28-36.

11. Mandal, S., \& Bapna, J. S. (2016). Pharmacological evaluation of Boerhavia diffusa plant extract for their potential in management of diabetic nephropathy in Streprozotocin induced Type I diabetic rats 5(12), 1097-1108.

12. Murti, K., Panchal, M. A., \& Lambole, V. (2010). Pharmacological properties of Boerhaavia diffusa - a review. Int J Pharm Sci Rev Res, 5(2), 107-110.

13. Nayak, P., \& Thirunavoukkarasu, M. (2016). A review of the plant Boerhaavia diffusa: Its chemistry, pharmacology and therapeutical potential. J. Phytopharmacol, 5(2), 83-92.

14. Nomani, I., Mazumder, A., \& Chakraborthy, G. S. (2013). Wedelia chinensis (Asteraceae)-An Overview Of A Potent Medicinal Herb. Int J PharmTech Res, 5(3), 957-964.

15. Ramesh, K., Manohar, S., \& Rajeshkumar, S. (2014) Nephroprotective activity of ethanolic extract of Orthosiphon stamineus leaves on ethylene glycol induced urolithiasis in albino rats. J. PharmTech Res, 6(1), 403-408.

16. Reshma, A. K., \& Brindha, P. (2014). In Vitro Anti-Inflammatory, Antioxidant and Nephroprotective Studies on Leaves of Aegle Marmelos and Ocimum Sanctum. Asian journal of pharmaceutical and clinical research, 7, 121-124.

17. Sasidharan, S., Aravindran, S., Latha, L. Y., Vijenthi, R., Saravanan, D., \& Amutha, S. (2010). In vitro antioxidant activity and hepatoprotective effects of Lentinula edodes against paracetamol-induced hepatotoxicity. Molecules, 15(6), 4478-4489.

18. Srinivasan, V., Panneerselvam, R., \& Gunasekaran, S. (2015). Nephro-protective Activity of Ethanolic Extract of Melia Azadirachta against $\mathrm{H}_{2} \mathrm{O}_{2}$ Induced Toxicity in Vero Cell Line.

19. Sundararajan, R., Bharampuram, A., \& Koduru, R. (2014). A review on phytoconstituents for nephroprotective activity. Pharmacophore, 5(1).

20. Surendran, S., Eswaran, M. B., Vijayakumar, M., \& Rao, C. V. (2011) In vitro and in vivo hepatoprotective activity of Cissampelos pareira against carbon-tetrachloride induced hepatic damage. Talwani, R., Gilliam, B. L., \& Howell, C. (2011). Infectious diseases and the liver. Clinics in liver disease, 15(1), 111-130. 


\section{AUTHORS PROFILE}

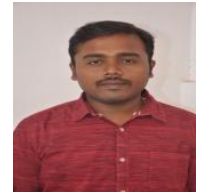

S J Kabilan, completed his B.Tech (Biotechnology) at Kalasalingam University and M.Tech (Biotechnology) at Kumaraguru College of Technology (Affiliated to Anna University). Both the Degrees completed with First class with Distinction. Also, pursuing $\mathrm{PhD}$ in the area of Herbal Drug Research.

Currently Employment: Assistant Professor, Department of Biotechnology, School of Bio and Chemical Engineering, Kalasalingam Academy of Research and Education, Tamilnadu, India.

Previous Publications: Kabilan, M. S. (2018). Antioxidant and anti-inflammatory properties of G-immune plus: A polyherbal formulation. International Journal of Green Pharmacy (IJGP), 12(03).

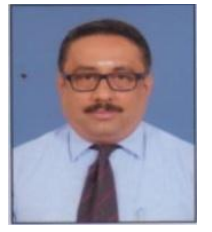

Dr. R. Baskar, $\mathrm{PhD}$ in Medical Biochemistry. Currently working as Associate professor at Kumaraguru college of Technology, Coimbatore, Tamilnadu, India.

Memberships:

Life Member in Indian Society for Technical Education Life Member in National Society for Ethnopharmacology.

Achievements:

1. INSA Summer Fellowship award during 2012 to work in the Laboratory of Plant-Microbe Interaction, School of Botany, University of Hyderabad on "Plant Growth Promoting Rhizobacteria".

2. Reviewer in National and International Journals

3. Currently Academic Editor in Biotechnology Journal International.

4. No. of citations : 792; h index : $12 ; \mathrm{i} 10$ index : 16

Recent Publications:

- Baskar,R., Akshaya, S.B., Akshitha, R., Dhilip Kumar, G. , Poorani, G. (2018).Evaluation of antioxidant and phytochemical activity in solvent extracts of Delonix regia.International Journal of Green Pharmacy, Volume 12(3), July-September issue, S607-S616.

- Baskar, R., Sweatha, S., Karunambika, R., G.Ramya, R.Shanthi (2017).

Influence of methionine on ergothineine content and antioxidant activity of Pleurotus platypus.Asian Journal of Microbiology, Biochemistry and Environmental Sciences, Volume 19 (Supplementary issue), S34-S38.

- Gurumallesh, P., Alagu, K., Ramakrishnan, B. and Muthusamy, S (2019).A systematic reconsideration on proteases.International Journal of Biological Macromolecules, 128, 254-267 (Impact Factor: 4.7)

- PooraniGurumallesh, Baskar Ramakrishnan and BhaarathiDhurai (2019). A novel metalloprotease from banana peel and its biochemical characterization. International Journal of Biological Macromolecules, 134, 527- 535 (Impact factor: 4.7)

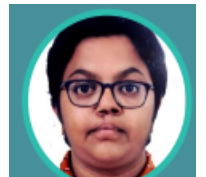

Poorani G completed her B.Tech (Biotechnology) at Tamil Nadu Agricultural University, Coimbatore and M.Tech Pharmaceutical Technology at SASTRA University, Thanjavur and currently pursuing Ph.D Kumaraguru College of Technology.

Notable Publications:

INTERNATIONAL

JOURNAL

$\mathrm{OF}$

BIOLOGICAL

MACROMOLECULES (2019) IF 4.78 A novel metalloprotease from banana peel and its biochemical characterization

MATERIAL SCIENCE AND ENGINEERING C (2019) IF 5.08 Biological synergy of greener gold nanoparticles by using Coleus aromaticus leaf extract

INTERNATIONAL JOURNAL OF BIOLOGICAL MACROMOLECULES (2019) IF 4.78 A systematic reconsideration on proteases

PROCESS BIOCHEMISTRY (2019) IF 2.88 Green synthesis of anisotropic silver nanoparticles from the aqueous leaf extract of Dodonaeaviscosa with their Antibacterial and Anticancer activities

JOURNAL OF PHOTOCHEMISTRY AND PHOTOBIOLOGY B: BIOLOGY (2018) IF 4.06 Improved Conductivity and Antibacterial activity of poly (2- aminothiophenol) - silver nanocomposite against human pathogens

JOURNAL OF MICROENCAPSULATION (2016) IF 2.04 Formulation, characterization, in vitro and in vivo evaluation of castor oil based self-nano emulsifying levosulpiride delivery systems 